\title{
Physicochemical Characteristics and Microbial Quality of an Oil Polluted Site in Gokana, Rivers State.
}

\section{${ }^{1}$ JOEL, OGBONNA F.; ${ }^{2}$ AMAJUOYI, CHINOMSO A.}

\author{
${ }^{1}$ Department of Petroleum and Gas Engineering, \\ Faculty of Engineering, University of Port Harcourt, Nigeria. \\ ${ }_{2}^{2}$ Pollution Control and Environmental Management Limited, Port Harcourt, Nigeria.
}

\begin{abstract}
Samples were collected from the soil surface area, the water surface, sub-surface sediment sand, sand from the river shore, Dead Sea food and dead mangrove vegetation leaves. Test results indicated that the Total Heterotrophic Bacteria (THB) values ranged from $\left(9.0 \times 10^{3}-2.6 \times 10^{6}\right) \mathrm{cfu} / \mathrm{ml}$ with the sample from the water surface having the highest value $\left(2.6 \times 10^{6}\right) \mathrm{cfu} / \mathrm{ml}$ and the least with the sample from the sub-surface $\left(9.0 \times 10^{3}\right)$ $\mathrm{cfu} / \mathrm{g}$. The Total coliforms values ranged from $\left(6.9 \times 10^{3}-2.3 \times 10^{6}\right) \mathrm{cfu} / 100 \mathrm{~g}$ with sample from the dead vegetation leaves having the highest value $\left(2.3 \times 10^{6}\right) \mathrm{cfu} / 100 \mathrm{~g}$ and the least value from the sample from mangrove substrate $\left(6.9 \times 10^{3}\right) \mathrm{cfu} / 100 \mathrm{~g}$. Among the physico-chemical parameters tested, TDS, lead, copper, chromium, cobalt, zinc, cadmium, nickel and arsenic were within acceptable limits as specified by regulatory agents. However, electrical conductivity, oil and grease, and iron were very high and above specified limits. The $\mathrm{pH}$ values ranged from $3.90-$ 8.15 with the sample from the mangrove substrate having the highest value (8.15) and the lowest value was from the sample from the crude on water surface (3.90). The electrical conductivity values ranged from $(1275-3565) \mu \mathrm{S} / \mathrm{cm}$ with sample from crude band on soil surface having the highest value (3565) $\mu \mathrm{S} / \mathrm{cm}$ and the lowest value from the sample from the sub-surface sediment sand (1275) $\mu \mathrm{S} / \mathrm{cm}$. The oil and grease values ranged from $(620-32040)$ $\mathrm{mg} / \mathrm{kg}$ with sample from soil surface having the highest value $(32040) \mathrm{mg} / \mathrm{kg}$ and the lowest value from the river shore sand (620) $\mathrm{mg} / \mathrm{kg}$. The high level of oil and grease contamination poses a concern. This therefore, validates the concern that releases of large quantities of oil to aquatic and terrestrial environments present a long term threat to all forms of life. @ JASEM
\end{abstract}

On land, crude oil spills have caused great negative impact on food productivity. For example, a good percentage of oil spills that occurred on the dry land between 1978 and 1979 in Nigeria, affected farmlands in which crops such as rice, maize, yams, cassava plantain were cultivated (Onyefulu and Awobajo, 1979). Crude oil affects germination and growth of some plants (Onwurah 1999a). It also affects soil fertility but the scale of impact depends on the quantity and type of oil spilled. Spilled petroleum hydrocarbons in the environment are usually drawn into the soil due to gravity until an impervious horizon is met, for example bedrock, watertight clay or an aquifer. Poor miscibility of crude oil accounts for accumulation of free oil on the surface of ground water and this may migrate laterally over a wide distance to pollute other zones very far away from the point of pollution. Industrial and municipal discharges as well as urban run-offs, atmospheric deposition and natural seeps also account for petroleum hydrocarbon pollution of the environment. It is worthy of note that groundwater is one of the many media by which human beings, plants and animals come into contact with petroleum hydrocarbon pollution. Crude oil and petroleum are complex mixtures of several polycyclic aromatic compounds and other hydrocarbons (Domask, 1984). Contamination of soil arising from spills is one of the most limiting factors to soil fertility and hence crop productivity (Onwurah et al., 2007). Report revealed that thirteen years after the Exxon Valdez oil spill in Prince William Sound, the toxic effects are still being felt due to the remaining bulk of the less-weathered subsurface oil (Short, et al., 2002). A random sampling of underground fuel storage tanks conducted by U.S. Environmental Protection Agency (USEPA) in the United States revealed about 35\% leaks in these tanks (United Press International, 1986). The major concern with crude oil spill has been its contamination of ground water, and the subsequent clean up.

Crude oil pollution of the environment may arise from oil well drilling production operations, transportation and storage in the upstream industry, and refining, transportation, and marketing in the downstream industry. It could also be from anthropogenic sources (Oberdorster and Cheek, 2000). Sources of petroleum and its products in the environment will also include accidental spills and from ruptured oil pipelines (Beller, et al., 1996). One of the major fates of spilled petroleum oil in the coastal environment is its incorporation into the sediments (Alexander and Webb, 1987). Problems associated with the study and remediation of the polluted ecosystem can be very expensive. The legal problems related to compensation in terms of assigning monetary reward may bring serious controversy. This study is therefore undertaken to determine the extent of oil pollution on a polluted site 
by investigating the physicochemical characteristics and microbial qualities of some selected parameters.

\section{MATERIALS AND METHODS}

Samples for Physicochemical and Microbiological Analyses

Samples were taken at different depths and distances from crude band on muddy area, film of crude on water surface, sub-surface sediment sand, surface black mud with crude spill, sand collected on river shore, dead sea food and dead mangrove vegetation leaves.

About $1 \mathrm{~kg}$ soil materials were collected in plastic bags and sampling protocols in line with analytical procedures as outlined in Part VII Section D of Guidelines and Standards for the Petroleum Industry were followed. One litre of effluent sample was collected and stored ice block cooler for preservation before being transferred to the laboratory for analysis (DPR, 1991; FEPA, 1991).

The need for sampling at the various points was to determine the extent of pollution in terms of percolation and dispersion plume. All the collected samples were preserved in accordance with guidelines and International Standards. All other QA/QC procedures relevant to sample collection, custody and analyses were strictly adhered to (APHA 1995; ASTM, 1979).

Due diligence were taken to prepare them for specified tests as indicated below.

\section{pH Value Determination}

The $50 \mathrm{ml}$ beaker was half-filled with the samples. Water was added to just sufficient depth to allow immersion of the electrode. Mixing was carried out using a gentle shaker and stirred frequently for a few minutes. Then allowed to stand for a further 15 minutes. The electrode of the meter was immersed into the slurry and waited for needle drift to cease. The $\mathrm{pH}$ was recorded for each sample.

\section{Electrical Conductivity (EC) determination}

A saturated paste of the crushed/ soil samples were made using distilled water. The electrical conductivity of the samples was determined electrometrically with a calibrated electrical conductivity meter.

\section{Heavy Metals Determination}

A measured quantity of the samples were transferred into a Kjeldahl flask; $20 \mathrm{ml}$ of concentrated nitric acid $\left(\mathrm{HNO}_{3}\right)$ was added and the sample pre-digested by heating gently for $20 \mathrm{mins}$. More acid was thereafter added and digestion was continued for 30-40mins. Digestion was stopped when a clear digest was obtained. The flask was cooled and the content transferred into a $50 \mathrm{ml}$ volumetric flask and made to the mark with distilled water. The resulting solution was analysed for heavy metals using the Atomic Absorption Spectrophotometer (AAS).

\section{Oil \& Grease Determination}

The soil sample was mixed using a glass rod or spatula. The samples were dried in the oven at $105^{\circ} \mathrm{C} \pm 2{ }^{\circ} \mathrm{C}$ for two hours (2Hrs). The dried material was disaggregated by gently crushing any lumps in a mortar. About $5.0 \mathrm{~g}$ of the sample was weighed into a $120 \mathrm{ml}$ glass bottle for extraction. About $20 \mathrm{ml}$ of the solvent was added into the bottle and extracted in a vibrating bath for three hours, allowed to settle and filtered into a clean bottle. The concentration was determined photometrically.

\section{Total Heterotrophic Bacteria For Soil Samples}

About $1.0 \mathrm{~g}$ of grounded soil $/$ sediment samples were aseptically transferred, using a flame- sterilized steel spatula, into a sterile test tube containing $9 \mathrm{ml}$ of the diluent. This gave $10^{-1}$ dilution. Subsequently, four fold $\left(10^{-4}\right)$ serial dilutions were prepared from the $10^{-}$ ${ }^{1}$ dilution.

\section{For Water Samples}

About $1 \mathrm{ml}$ of the crude/film of crude on water surface samples was aseptically transferred, using a sterilized dropper, into a sterile test tube containing $9 \mathrm{ml}$ of the diluent. This gave $10^{-1}$ dilution. Subsequently, four fold $\left(10^{-4}\right)$ serial dilutions were prepared from the $10^{-1}$ dilution.

\section{Inoculation and Enumeration of Both Water and Soil Samples}

$0.1 \mathrm{ml}$ aliquot of $10^{-4}$ dilution was aseptically removed with a sterile pipette and spread plated with flame sterilized glass spreader on well dried agar plates. This was incubated at $28 \pm 2^{\circ} \mathrm{C}$ for $24 \mathrm{hrs}$. The colonies counted were expressed as colony forming unit per gram for soil/sediment/dead sea food/dead mangrove vegetation leaves and colony forming unit for water samples.

\section{Total Coliforms \\ For Soil Samples}

About $1.0 \mathrm{~g}$ of grounded soil/sediment samples were homogenized with $20 \mathrm{ml}$ of distilled water in $100 \mathrm{ml}$ volumetric flask. Then make up to the mark with distilled water. This should be done in triplicates. This gives a dilution factor of $10^{2}$. The diluted samples were filtered through membrane filter with the aid of vacuum pump. The filter membrane was placed in the m-HPC agar plate. This was then

\footnotetext{
* Corresponding author: Joel, Ogbonna F.
} 
incubated using an incubator pre-set to $28 \pm 2^{\circ} \mathrm{C}$ for 24hrs. Observation was made for colony development on the filter membrane. The colonies were then counted as colony forming unit per $100 \mathrm{~g}$.

\section{For Water Samples}

About $100 \mathrm{ml}$ of the crude/film of crude on water surface samples was filtered through membrane filter with the aid of vacuum pump. The filter membrane was placed in the m-HPC agar plate. This was then incubated using an incubator pre-set to $28 \pm 2^{\circ} \mathrm{C}$ for 24hrs. Observation was made for colony development on the filter membrane. The colonies were then counted as colony forming unit per $100 \mathrm{ml}$.

\section{RESULTS AND DISCUSSION}

Test results from samples as specified are indicated in the tables as below.

Table 1: Microbiological Quality of Crude Band on Muddy Area (Sample 1)

\begin{tabular}{|l|l|l|}
\hline S/N & Parameter & Test result \\
\hline 1. & Total Heterotrophic Bacteria $(\mathrm{cfu} / \mathrm{g})$ & $9.0 \times 10^{3}$ \\
\hline 2. & Total Coliforms $(\mathrm{cfu} / 100 \mathrm{~g})$ & $8.0 \times 10^{5}$ \\
\hline
\end{tabular}

Table 2: Microbiological Quality of Film of Crude on Water Surface (Sample 2)

\begin{tabular}{|l|l|l|}
\hline $\mathrm{S} / \mathrm{N}$ & Parameter & Test result \\
\hline 1. & Total Heterotrophic Bacteria $(\mathrm{cfu} / \mathrm{ml})$ & $2.6 \times 10^{6}$ \\
\hline 2. & Total Coliforms $(\mathrm{cfu} / 100 \mathrm{ml})$ & $2.1 \times 10^{6}$ \\
\hline
\end{tabular}

Table 3: Microbiological Quality of Sub-surface Sediment Sand, $0.5 \mathrm{~m}$ Deep (Sample 3)

\begin{tabular}{|l|l|l|}
\hline S/N & Parameter & Test result \\
\hline 1. & Total Heterotrophic Bacteria $(\mathrm{cfu} / \mathrm{g})$ & $6.2 \times 10^{2}$ \\
\hline 2. & Total Coliforms $(\mathrm{cfu} / 100 \mathrm{~g})$ & $6.0 \times 10^{5}$ \\
\hline
\end{tabular}

Table 4: Microbiological Quality of Surface Black Mud with Crude Spill (Sample 4)

\begin{tabular}{|l|l|l|}
\hline $\mathrm{S} / \mathrm{N}$ & Parameter & Test result \\
\hline 1. & Total Heterotrophic Bacteria $(\mathrm{cfu} / \mathrm{g})$ & $1.4 \times 10^{5}$ \\
\hline 2. & Total Coliforms $(\mathrm{cfu} / 100 \mathrm{~g})$ & $2.0 \times 10^{6}$ \\
\hline
\end{tabular}

Table 5: Microbiological Quality of Sand Collected on River Shore (Sample 5)

\begin{tabular}{|l|l|l|}
\hline $\mathrm{S} / \mathrm{N}$ & Parameter & Test result \\
\hline 1. & Total Heterotrophic Bacteria $(\mathrm{cfu} / \mathrm{g})$ & $1.5 \times 10^{3}$ \\
\hline 2. & Total Coliforms $(\mathrm{cfu} / 100 \mathrm{~g})$ & $1.4 \times 10^{5}$ \\
\hline
\end{tabular}

Table 6: Microbiological Quality of Dead Sea Food, Oyster on Mangrove Substrate (Sample 6)

\begin{tabular}{|l|l|l|}
\hline $\mathrm{S} / \mathrm{N}$ & Parameter & Test result \\
\hline 1. & Total Heterotrophic Bacteria $(\mathrm{cfu} / \mathrm{g})$ & $1.9 \times 10^{4}$ \\
\hline 2. & Total Coliforms $(\mathrm{cfu} / 100 \mathrm{~g})$ & $6.9 \times 10^{3}$ \\
\hline
\end{tabular}

Table 7: Microbiological Quality of Dead Vegetation Leaves (Sample 7)

\begin{tabular}{|l|l|l|}
\hline $\mathrm{S} / \mathrm{N}$ & Parameter & Test result \\
\hline 1. & Total Heterotrophic Bacteria $(\mathrm{cfu} / \mathrm{g})$ & $1.2 \times 10^{4}$ \\
\hline 2. & Total Coliforms $(\mathrm{cfu} / 100 \mathrm{~g})$ & $2.3 \times 10^{6}$ \\
\hline
\end{tabular}

Table 8: Physicochemical Analysis of Crude Band on Muddy Area (Sample 1)

\begin{tabular}{|l|l|l|}
\hline $\mathrm{S} / \mathrm{N}$ & Parameter & Test result \\
\hline 1. & $\mathrm{pH}$ & 6.70 \\
\hline 2. & TDS $(\mathrm{mg} / \mathrm{l})$ & 1758 \\
\hline 3. & EC $(\mu \mathrm{S} / \mathrm{cm})$ & 3565 \\
\hline 4. & Oil and Grease $(\mathrm{mg} / \mathrm{l})$ & 1956 \\
\hline 5. & Nickel $(\mathrm{mg} / \mathrm{l})$ & $<0.001$ \\
\hline 6. & Cadmium $(\mathrm{mg} / \mathrm{l})$ & $<0.001$ \\
\hline 7. & Chromium $(\mathrm{mg} / \mathrm{l})$ & 0.023 \\
\hline 8. & Cobalt $(\mathrm{mg} / \mathrm{l})$ & $<0.001$ \\
\hline 9. & Copper $(\mathrm{mg} / \mathrm{l})$ & 0.002 \\
\hline 10. & Lead $(\mathrm{mg} / \mathrm{l})$ & 0.006 \\
\hline 11. & Zinc $(\mathrm{mg} / \mathrm{l})$ & 0.057 \\
\hline 12. & Iron $(\mathrm{mg} / \mathrm{l})$ & 12.680 \\
\hline 13. & Arsenic $(\mathrm{mg} / \mathrm{l})$ & $<0.001$ \\
\hline
\end{tabular}

Table 9: Physicochemical Analysis of Film of Crude on Water Surface (Sample 2)

\begin{tabular}{|l|l|l|}
\hline $\mathrm{S} / \mathrm{N}$ & Parameter & Test result \\
\hline 1. & $\mathrm{pH}$ & 3.90 \\
\hline 2. & TDS $(\mathrm{mg} / \mathrm{l})$ & 1530 \\
\hline 3. & EC $(\mu \mathrm{S} / \mathrm{cm})$ & 3105 \\
\hline 4. & Oil and Grease $(\mathrm{mg} / \mathrm{l})$ & 1363 \\
\hline 5. & Nickel $(\mathrm{mg} / \mathrm{l})$ & $<0.001$ \\
\hline 6. & Cadmium $(\mathrm{mg} / \mathrm{l})$ & $<0.001$ \\
\hline 7. & Chromium $(\mathrm{mg} / \mathrm{l})$ & 0.113 \\
\hline 8. & Cobalt $(\mathrm{mg} / \mathrm{l})$ & $<0.001$ \\
\hline 9. & Copper $(\mathrm{mg} / \mathrm{l})$ & $<0.001$ \\
\hline 10. & Lead $(\mathrm{mg} / \mathrm{l})$ & $<0.001$ \\
\hline 11. & Zinc $(\mathrm{mg} / \mathrm{l})$ & 0.139 \\
\hline 12. & Iron $(\mathrm{mg} / \mathrm{l})$ & 0.574 \\
\hline 13. & Arsenic $(\mathrm{mg} / \mathrm{l})$ & 0.001 \\
\hline
\end{tabular}

Table 10: Physicochemical Analysis of Film of Sub-surface Sediment Sand, 0.5m Deep (Sample 3)

\begin{tabular}{|l|l|l|}
\hline $\mathrm{S} / \mathrm{N}$ & Parameter & Test result \\
\hline 1. & $\mathrm{pH}$ & 7.39 \\
\hline 2. & EC $(\mu \mathrm{S} / \mathrm{cm})$ & 1275 \\
\hline 4. & Oil and Grease $(\mathrm{mg} / \mathrm{kg})$ & 4960 \\
\hline 5. & Nickel $(\mathrm{mg} / \mathrm{kg})$ & 0.001 \\
\hline 6. & Cadmium $(\mathrm{mg} / \mathrm{kg})$ & $<0.001$ \\
\hline 7. & Chromium $(\mathrm{mg} / \mathrm{kg})$ & 0.002 \\
\hline 8. & Cobalt $(\mathrm{mg} / \mathrm{kg})$ & $<0.001$ \\
\hline 9. & Copper $(\mathrm{mg} / \mathrm{kg})$ & $<0.001$ \\
\hline 10. & Lead $(\mathrm{mg} / \mathrm{kg})$ & 0.002 \\
\hline 11. & Zinc $(\mathrm{mg} / \mathrm{kg})$ & 0.078 \\
\hline 12. & Iron $(\mathrm{mg} / \mathrm{kg})$ & 5.828 \\
\hline 13. & Arsenic $(\mathrm{mg} / \mathrm{kg})$ & $<0.001$ \\
\hline
\end{tabular}

* Corresponding author: Joel, Ogbonna F. 
Table 11: Physicochemical Analysis of Film of Surface Black Mud with Crude Spill (Sample 4)

\begin{tabular}{|l|l|l|}
\hline $\mathrm{S} / \mathrm{N}$ & Parameter & Test result \\
\hline 1. & $\mathrm{pH}$ & 7.45 \\
\hline 2. & EC $(\mu \mathrm{S} / \mathrm{cm})$ & 1436 \\
\hline 4. & Oil and Grease $(\mathrm{mg} / \mathrm{kg})$ & 32040 \\
\hline 5. & Nickel $(\mathrm{mg} / \mathrm{kg})$ & 0.001 \\
\hline 6. & Cadmium $(\mathrm{mg} / \mathrm{kg})$ & $<0.001$ \\
\hline 7. & Chromium $(\mathrm{mg} / \mathrm{kg})$ & $<0.001$ \\
\hline 8. & Cobalt $(\mathrm{mg} / \mathrm{kg})$ & $<0.001$ \\
\hline 9. & Copper $(\mathrm{mg} / \mathrm{kg})$ & $<0.001$ \\
\hline 10. & Lead $(\mathrm{mg} / \mathrm{kg})$ & 0.002 \\
\hline 11. & Zinc $(\mathrm{mg} / \mathrm{kg})$ & 0.078 \\
\hline 12. & Iron $(\mathrm{mg} / \mathrm{kg})$ & 18.47 \\
\hline 13. & Arsenic $(\mathrm{mg} / \mathrm{kg})$ & $<0.001$ \\
\hline
\end{tabular}

Table 12: Physicochemical Analysis of Sand Collected on River Shore (Sample 5)

\begin{tabular}{|l|l|l|}
\hline $\mathrm{S} / \mathrm{N}$ & Parameter & Test result \\
\hline 1. & $\mathrm{pH}$ & 7.64 \\
\hline 2. & EC $(\mu \mathrm{S} / \mathrm{cm})$ & 1771 \\
\hline 4. & Oil and $\mathrm{Grease}(\mathrm{mg} / \mathrm{kg})$ & 620 \\
\hline 5. & Nickel $(\mathrm{mg} / \mathrm{kg})$ & 0.002 \\
\hline 6. & Cadmium $(\mathrm{mg} / \mathrm{kg})$ & $<0.001$ \\
\hline 7. & Chromium $(\mathrm{mg} / \mathrm{kg})$ & $<0.001$ \\
\hline 8. & Cobalt $(\mathrm{mg} / \mathrm{kg})$ & $<0.001$ \\
\hline 9. & Copper $(\mathrm{mg} / \mathrm{kg})$ & 0.001 \\
\hline 10. & Lead $(\mathrm{mg} / \mathrm{kg})$ & $<0.001$ \\
\hline 11. & Zinc $(\mathrm{mg} / \mathrm{kg})$ & 0.038 \\
\hline 12. & Iron $(\mathrm{mg} / \mathrm{kg})$ & 3.237 \\
\hline 13. & Arsenic $(\mathrm{mg} / \mathrm{kg})$ & $<0.001$ \\
\hline
\end{tabular}

Table 13: Physicochemical Analysis of Dead Sea Food, Oyster on Man Substrate (Sample 6)

\begin{tabular}{|l|l|l|}
\hline $\mathrm{S} / \mathrm{N}$ & Parameter & Test result \\
\hline 1. & $\mathrm{pH}$ & 8.15 \\
\hline 2. & EC $(\mu \mathrm{S} / \mathrm{cm})$ & 1429 \\
\hline 4. & Oil and Grease $(\mathrm{mg} / \mathrm{kg})$ & 5360 \\
\hline 5. & Nickel $(\mathrm{mg} / \mathrm{kg})$ & 0.001 \\
\hline 6. & Cadmium $(\mathrm{mg} / \mathrm{kg})$ & $<0.001$ \\
\hline 7. & Chromium $(\mathrm{mg} / \mathrm{kg})$ & 0.098 \\
\hline 8. & Cobalt $(\mathrm{mg} / \mathrm{kg})$ & 0.001 \\
\hline 9. & Copper $(\mathrm{mg} / \mathrm{kg})$ & 0.001 \\
\hline 10. & Lead $(\mathrm{mg} / \mathrm{kg})$ & 0.006 \\
\hline 11. & Zinc $(\mathrm{mg} / \mathrm{kg})$ & 0.058 \\
\hline 12. & Iron $(\mathrm{mg} / \mathrm{kg})$ & 6.038 \\
\hline 13. & Arsenic $(\mathrm{mg} / \mathrm{kg})$ & 0.75 \\
\hline
\end{tabular}

Table 14: Physicochemical Analysis of Dead Vegetation Leaves (Sample 7)

\begin{tabular}{|l|l|l|}
\hline $\mathrm{S} / \mathrm{N}$ & Parameter & Test result \\
\hline 1. & $\mathrm{pH}$ & 5.95 \\
\hline 2. & EC $(\mu \mathrm{S} / \mathrm{cm})$ & 2158 \\
\hline 4. & Oil and Grease $(\mathrm{mg} / \mathrm{kg})$ & 19260 \\
\hline 5. & Nickel $(\mathrm{mg} / \mathrm{kg})$ & 0.002 \\
\hline 6. & Cadmium $(\mathrm{mg} / \mathrm{kg})$ & $<0.001$ \\
\hline 7. & Chromium $(\mathrm{mg} / \mathrm{kg})$ & 0.170 \\
\hline 8. & Cobalt $(\mathrm{mg} / \mathrm{kg})$ & $<0.001$ \\
\hline 9. & Copper $(\mathrm{mg} / \mathrm{kg})$ & $<0.001$ \\
\hline 10. & Lead $(\mathrm{mg} / \mathrm{kg})$ & 0.001 \\
\hline 11. & Zinc $(\mathrm{mg} / \mathrm{kg})$ & 0.071 \\
\hline 12. & Iron $(\mathrm{mg} / \mathrm{kg})$ & 3.714 \\
\hline 13. & Arsenic $(\mathrm{mg} / \mathrm{kg})$ & 0.35 \\
\hline
\end{tabular}

Results of the different samples from the different sampling locations of the soil surface, sub-surface $(0.5 \mathrm{~m})$ depth, water surface, river shore, mangrove substrate and dead vegetation leaves are presented in tables $(1-14)$. Tables $(1-7)$ are results for microbiological quality from the seven sample points while tables $(8-14)$ are for physicochemical analysis respectively.

Test results indicated that Total heterotrophic bacteria for soil surface sample (table 1) was $9.10 \times$ $10^{3} \mathrm{cfu} / \mathrm{g}, 2.6 \times 10^{6} \mathrm{cfu} / \mathrm{g}$ for water surface (table 2 ), $6.2 \times 10^{2} \mathrm{cfu} / \mathrm{g}$ for soil sub-surface $(0.5 \mathrm{~m})$ depth (table 3 ), $1.4 \times 10^{5} \mathrm{cfu} / \mathrm{g}$ for highly polluted soil surface (table 4), $1.5 \times 10^{3} \mathrm{cfu} / \mathrm{g}$ for the river shore sand (table 5), $1.9 \times 10^{4} \mathrm{cfu} / \mathrm{g}$ for mangrove substrate (table 6)and $1.2 \times 10^{4}$ for dead vegetation leaves (table 7). The result was higher with the sample from the water surface followed by the sample from highly polluted surface and least with the sample from the soil sub-surface $(0.5 \mathrm{~m})$ depth. The highest number of microbial load seen with sample from water surface geoverld be attributed to activities, nutrient and aeration at the surface that enhances microbial growth and the least number seen in the sub-surface could be attributed to anaerobic conditions and nutrient depletion that inhibits microbial growth.

The total coliforms ranged from $6.9 \times 10^{3}-2.30 \times$ $10^{6} \mathrm{cfu} / 100 \mathrm{~g}$ (table $1-7$ ). With the sample from the dead vegetation leaves giving the highest number and the least from the sample from mangrove substrate (table 6). There is a strong indication that the dead vegetation leaves provided a fertile ground for the microbes to grow while mangrove substrate lack necessary nutrients to favour the growth of the microbes.

As specified in the guidelines for Environmental officers (EHO's) limit for food materials, the total coliforms results were higher with sample from

* Corresponding author: Joel, Ogbonna F. 
Oyster mangrove substrate and dead vegetaion leaves.

The physicochemical results are presented in tables (8-14). Among the parameters tested, TDS, lead, copper, chromium, zinc, cobalt, cadmium, nickel and arsenic were within acceptable limit as specified by regulatory agents. However, electrical conductivity, oil and grease, iron and $\mathrm{pH}$ were very high and above specified limits. The $\mathrm{pH}$ value ranged from $(3.90-$ 8.15). The highest was with the sample from the mangrove substrate and lowest was from the water surface sample. The varoius contaminants in the water surface would have resulted to increase of the acidity level of the water body thereby lowering the $\mathrm{pH}$ value as seen. The electrical conductivity ranged from (1275-3565) $\mu \mathrm{S} / \mathrm{cm}$ with highest value seen with the sample from soil surface (table-8) and least with sample from sub-surface soil (table-10). Electrical conductivity levels are affected by geology and soils constituents (Boyd,1982). The oil and grease values ranged from (620-32040) $\mathrm{mg} / \mathrm{kg}$, with the highest value seen in the highly polluted soil surface sample (table-11) and the least in the river shore sample (table -12). The high level of contamination with oil and grease poses a great concern and long term threat to all forms of life.

Conclusion: When oil spill occurs, it poses a long term threat to all forms of life. To address this concern, immediate remediation technology should be carried out to restore affected areas to base - line level. Due diligence to be adhered to for continuous monitoring to validate the effectiveness of mitigation.

\section{REFERENCES}

Alexander, SK and Webb, JW (1987). Relationship of Spartina alterniflora growth to sediment oil content following on oil spill. Proceeding of the 1987-Oil Spill Conference, American Petroleum Institute, Washington, DC, 445-449.

APHA (1995). Standard Methods for the Examination of Water/ Waste water. APHAAWWA-WPCF, Washington D. C. 20036.

ASTM (1979). Annual Book of America Society for Testing and Materials Standards, 1527, Philadelphia.

Beller, M., Schoenmaker, H., Huuskonen, E., (1996). Pipeline inspection environmental protection through on-line inspection, Proceeding of the NNPC Seminar In: Oil industry and the Nigerian Environment, Port Harcourt, Nigeria, pp 233241.
Boyd, CE (1982). Water Management for pond fish culture. Elsevier Scientific Publications, Amsterdam, Development on Aquaculture and Fisheries Science, Vol 9 Pg. 231.

Domask, WG (1984). Introduction to petroleum hydrocarbons. Chemistry and composition in relation to petroleum derived fuels and solvents. Renel Effects of petroleum hydrocarbons. Adv. Nod. Environ. Tox. 8, 1-26.

DPR (1991). Department of Petroleum Resources, 1991, Environmental Guidelines and Standards for the Petroleum Industry in Nigeria. Production and Terminal Operations. Department of Petroleum Resources, Ministry of Petroleum Resources, Lagos.

FEPA (1991). Federal Environmental Protection Agency, 1995. Corporate Profile, Garki, FCT, Abuja, Nigeria.

Oberdorster, E., Cheek, AO (2000). Gender benders at the beach, endocrine disruption in marine and estuarine organisms. Environ. Toxicol. Chem., 20 (4), 23-36.

Onwurah, INE (1999a). Restoring the crop sustaining potential of crude oil polluted soil by means of Azotobacter inoculation. Plant Prod. Res, J., 4, 6-16.

Onwurah, INE, Ogugua, VN, Onyike, NB, Ochonogor, AE and Otitoju, OF (2007). Crude Oil Spills in the Environment, Effects and Some Innovative Clean-up Biotechnologies. International Journal of Environmental Research. International Journal of Environmental Research, 1(4), 307-320.

Onyefulu, KO, Awobajo, OA (1979). Environmental Aspects of the Petroleum Industry in the Niger Delta, Problems and Solutions. In the Petroleum Industry and Niger Delta. Proceedings of the NNPC Seminar on Environment.

Short, JW, Lindeberg, MR, Harris, PM, Maslko, J, Rice, SD, (2002). Vertical Oil Distribution within Inter-tidal zone 12 years after the Exxon Valdez oil spill in Prince William Sound, Alaska. Proceedings, $25^{\text {th. }}$ Arctic and Marine Oil spill Program. Calgary, Alberta, Canada. June, 11-13, 57-72.

United Press International (1986). Gasoline Reported threatening water' Boston Globe, June 25.

* Corresponding author: Joel, Ogbonna F. 